\title{
Isolation and Characterization of Stream Water Bacteria from ESA-OKE Metropolis
}

\author{
Olagoke $\mathrm{OV}^{1,2^{*}}$, Awojobi KA ${ }^{2}$, Adekeye $\mathrm{AA}^{3}$, Olasupo $\mathrm{AD}^{4}$, Aborisade $\mathrm{AB}^{5}$ and Ogunrinde $\mathrm{TO}^{1}$ \\ ${ }^{1}$ Department of Agricultural Development Management (ADEM), Agricultural and Rural Management Training Institute (ARMTI), Ilorin, Nigeria \\ ${ }^{2}$ Department of Microbiology, Agricultural and Rural Management Training Institute (ARMTI), Ilorin, Nigeria \\ ${ }^{3}$ Department of Rural Development and Gender Issue (RUDEG), Agricultural and Rural Management Training Institute (ARMTI), Ilorin, Nigeria \\ ${ }^{4}$ Department of Chemistry, Ladoke Akintola University of Technology Ogbomoso, Oyo State, Nigeria \\ ${ }^{5}$ Department of Biochemistry, Ladoke Akintola University of Technology Ogbomoso, Oyo State, Nigeria
}

*Corresponding author: Olagoke OV, Department of Agricultural Development Management (ADEM), Agricultural and Rural Management Training Institute (ARMTI), Ilorin, Nigeria, Tel: 234803487 6488; E-mail: victorolagoke@yahoo.com

Rec: Apr 05, 2018, Acc: May 30, 2018, Pub: Jun 04, 2018

Copyright: ( $) 2018$ Olagoke OV, et al. This is an open-access article distributed under the terms of the Creative Commons Attribution License, which permits unrestricted use, distribution, and reproduction in any medium, provided the original author and source are credited.

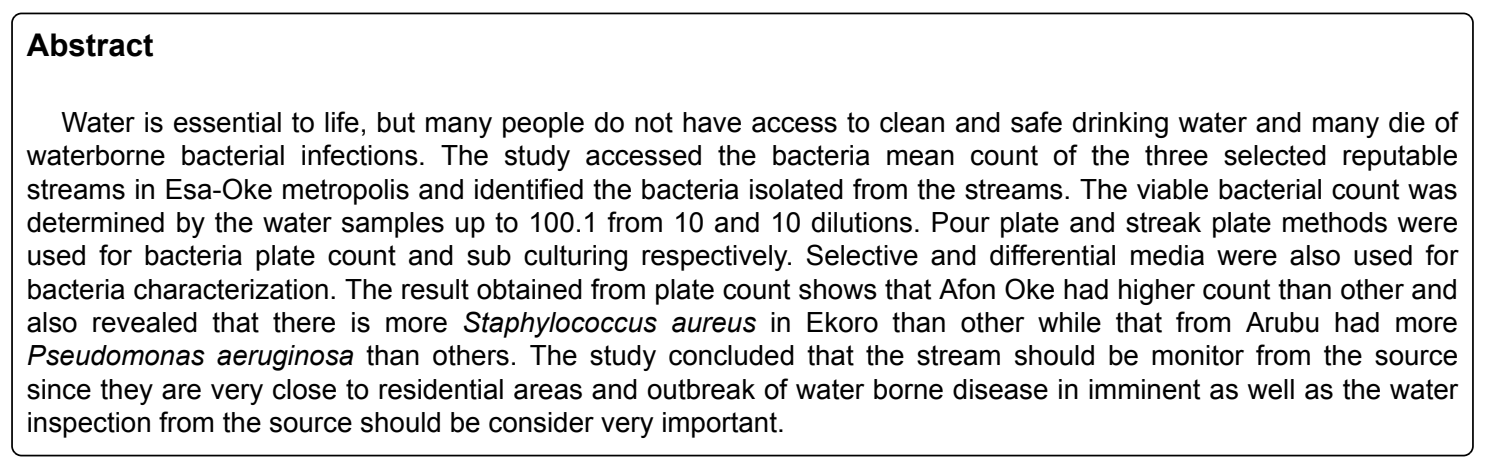

Keywords: Bacterial infections; P. aeruginosa; S. aureus

\section{Introduction}

Water is essential to life in adequate, safe and accessible supply which in turns provides significant benefit to health [1]. Our body, being primarily water, requires sufficient daily water replacement in order to function efficiently because water involved in all bodily functions such as digestion, assimilation, elimination, respiration, maintaining temperature (homeostasis) integrity and the strength of all bodily structures [2]. A clean and treated water supply to each house has been the norm in Europe and North America but in developing countries, access to both clean water and sanitation are not the rule and waterborne infections are common [2]. Two and a half billion people have no access to improved sanitation, and more than 1.5 million children die each year from diarrheal disease [3]. According to the World Health Organization, the mortality of water associated disease exceeds 5 million people per year in which microbial intestinal infections are more than $50 \%$, with cholera standing out in the first place [4].

Water is polluted with hundreds of toxins and impurities and authorities only test for a small number of them [2]. Water treatments, that are aimed to render our drinking water bacteriological safe, have been proven ineffective and the presence of certain pathogenic bacteria like giardia and cryptosporidium recently found in Sydney water is just one of the many examples [3]. Viewing the effects of individual chemicals, inorganic minerals and their by-products, you can see a link to today's major diseases [4]. Mineral water may be wonderful to bathe; however, the presence of some pathogens and inorganic minerals makes it undesirable [1]. Microbial waterborne disease also affects developed countries. In the USA, it has been estimated that each year 560,000 people suffer from severe waterborne diseases, and 7.1 million suffer from a mild to moderate infections, resulting in estimated 12,000 deaths a year $[5,6]$. Acute microbial diarrheal diseases are a major public health problem in developing countries and people affected by diarrheal disease are those with the lowest financial resources and poorest hygienic facilities [2]. Children under five, primarily in Asian and African Countries, are most affected by microbial idea se transmitted through water [7].

In developing countries like Nigeria, where access to both clean water and sanitation are not the rule and waterborne infections are common that leads to increase in morbidity and mortality among people. Therefore, the study accessed the bacteria mean count of the three selected reputable streams in Esa-Oke metropolis and identified the bacteria isolated from the streams. This will help to provide adequate information for the community to enhance improvement in the healthiness of drinking water especially from the streams in the community.

\section{Methodology \\ Collection of sample}

Three streams water (Afon, Arubu and Ekoro) were collected in Esa-Oke metropolis into different sterile conical flask covered with aluminum foil. Aseptically, the cap cover of each flask was removed, and the mouth was face upstream (i.e., towards the flow of the water) and plugged the neck downwards about $30 \mathrm{~cm}$ below the water surface 
Page 2 of 3

and filled completely before carefully replaced the cap cover and thereafter labeled each bottle with the sample code number and the samples were then quickly taken with the iced pack to the laboratory for bacteriological examination.

\section{Culture media}

The culture media were prepared following the manufacture direction. The culture media used for isolation, stocking and for biochemical characterization of the bacteria isolates were eosin methylene blue agar (EMB), Nutrient agar, MacConkey broth, Blood agar, Mannitol salt agar (MSA)and Nutrient broth.

\section{Determination of viable bacteria mean count}

The viable bacterial count was determined by the water samples up to 100.1 from 10 and 10 dilutions was taken and introduced into sterile Petri dishes. Pour plate method was used after pouring the agar into plates containing the serially diluted water samples. It was swirled and allowed to set before incubating at $37^{\circ} \mathrm{C}$ for 48 hours. Colonies that developed on the plate were counted and recoded.

\section{Purification and preservation of isolate}

This was done distinct colonies onto another sterile nutrient agar plates and incubated at $37^{\circ} \mathrm{C}$ for 24 hours, after 24 hours of incubation the colonies were inoculated onto agar slants and re-incubated again. The agar slants were preserved in refrigerator at the temperature of 4 to $8^{\circ} \mathrm{C}$

\section{Characterization and identification of bacterial isolates}

The characterization was done based on the colonial morphology, biochemical characteristic and cellular morphology. The colonial morphological was observed with an unaided eye, the following morphological feature were used for the characterization; Colony shape, Elevation, Size, Edge. Gram staining and spore staining were carried out after which they were subjected to biochemical by Fawole and Oso [8].

\section{Result}

The results of bacteria mean count and bacterial isolates distribution data analysis shows in the tables below (Tables 1 and 2).

\begin{tabular}{|l|l|}
\hline Sample & Bacteria mean count \\
\hline Afon-Oke & $1.15 \times 10^{8}$ \\
\hline Arubu & $1.13 \times 10^{7}$ \\
\hline Ekoro & $1.02 \times 10^{7}$ \\
\hline
\end{tabular}

Table 1: Profile of bacterial mean count.

\begin{tabular}{|c|c|c|c|}
\hline \multirow{2}{*}{ Bacterial isolate } & \multicolumn{3}{|l|}{ Sample } \\
\hline & Afon-Oke & Arubu & Ekoro \\
\hline $\begin{array}{l}\text { Staphylococcus } \\
\text { aureus }\end{array}$ & 3 & 6 & 7 \\
\hline $\begin{array}{l}\text { Staphylococcus } \\
\text { spp }\end{array}$ & 2 & 2 & 5 \\
\hline
\end{tabular}

\begin{tabular}{|l|l|l|l|}
\hline Bacillus subtilis & 2 & 4 & 2 \\
\hline $\begin{array}{l}\text { Klebsiella } \\
\text { pnuemoniae }\end{array}$ & 3 & 3 & 1 \\
\hline $\begin{array}{l}\text { Pseudomonas } \\
\text { aeruginosa }\end{array}$ & 1 & 5 & 1 \\
\hline
\end{tabular}

Table 2: Distribution of bacterial isolate among samples.

\section{Discussion}

The result obtained from plate count shows that Afon Oke had higher count than other (Table 1). The study revealed that there is more Staphylococcus aureus in Ekoro than other while that from Arubu had more $P$. aeruginosa than others. $S$. aureus was the most predominant bacterial isolates encountered. Pathogenic bacteria are known to elaborate various extracellular products that may contribute to their virulence in host. Some of the extracellular products include enzymes and toxins. Some of this enzymes and toxin are important in virulence of this microorganism. The result obtained from this study shows that all $S$. aureus were coagulase and DNAse positive which may be as a result of the 'coo' gene. All $S$. aureus were B-hemolytic which appears as a clear zone on blood agar. This revealed that this organism could lyse the red blood cell of the host when ingested and could result in water borne disease. $S$. aureus has been known to cause poisoning, through it is self-limiting, it causes prolonged vomiting, diarrheadehydration and loss of electrolyte in the very young and old [9], because immunity is immature and overwhelm at both extremity in a companion study in Ago-Iwoye town, Ogun State. Nigeria the investigators reported that most of the water sample contained Bacillus (about 84.62\%) organism, whereas Staphylococcus and Pseudomonas spp placed second and third higher position having 65.72 and $76.84 \%$ isolation.

Staphylococcus species are found in everywhere. Most species of Staphylococcus can produce some form of enterotoxin, the causative agent of Staphylococcal enteritis [10].

Staphylococcus spp was second to $S$. aureus in predominance. Staphylococcus spp are not usually pathogenic but can cause infection in immunocompromised individuals as opportunistic organisms [9]. The results show that the Staphylococcus spp identified did not clot the human plasma and were B-heamolytic. Bacillus spp are Gram positive rods that are spore formers. They are found mainly in the soil, dirty equipment [11]. P. aeruginosa in this study was found in Ekoro, Arubu, and Afon-Oke. Other studies have reported that Pseudomonas spp is ubiquitous, heat loving bacteria which are usually seen in small amount in feaces [12]. The Pseudomonas spp was the second in predominance of all the bacterial isolate recovered in Arubu.

Klebsiella pnuemoniae was also isolated from the three streams and is one of the coliform bacteria that can be opportunistic pathogenic bacteria if found in high proportion in human intestine. They are generally found in soil, water, food and dirty materials.

\section{Conclusion}

The higher number of bacterial is alarming as the international microbiological standard specify that bacterial plate count should be less than $105 \mathrm{Cfu} / \mathrm{g}$ of coliform and should not exceed the range of 101 to $102 \mathrm{cfu} / \mathrm{g}$. However, the need for improved quality control in stream 
Citation: Olagoke OV, Awojobi KA, Adekeye AA, Olasupo AD, Aborisade AB, et al. (2018) Isolation and Characterization of Stream Water Bacteria from ESA-OKE Metropolis. J Med Microb Diagn 7: 276. doi:10.4172/2161-0703.1000276

Page 3 of 3

water cannot be over emphasized and good hygiene practices should not be ruled out. The stream should be monitor from the source since they very close to residential areas and outbreak of water borne disease in imminent as well as water inspection from the source should be consider very important. The bacteria gaining access to water was not only the indication of deterioration but also a warning sign of the presence of many water-borne pathogens, clean environment play an important and vital role. As most of the isolated bacteria were able to produce toxins, it is recommended for strict monitoring and certification of the streams hoping to maintain quality of stream and ultimately to ensure good health.

\section{References}

1. World Health Organization (2008) Guideline for drinking-water quality Incorporating $1^{\text {st }}$ and $2^{\text {nd }}$ addenda, volume I, recommendations [3rd edn], WHO: Geneva, Switzerland.

2. João PSC (2010) Water microbiology. Bacterial pathogens and water. Int J Environ Res Public Health 7: 36570-36703.

3. Fenwick A (2006) Waterborne diseases-could they be consigned to history? Science 313: 1077-1081.

4. George I (2001) Crop, B-D-Galactosidase and B-D-Glucuronidase activities for quantitative detection of total and faecal coliforms in wastewater. Can J Microbiol 47: 670-675.
5. Medema GJ, Payment P, Dufour A, Robertson W, Waite M, et al. (2003) Safe drinking water: An ongoing challenge. In assessing microbial safety of drinking water. Improving approaches and method, WHO and OECD, IWA Publishing: London, UK, pp: 11-45.

6. Medema GJ, Shaw S, Waite M, Snozzi M, Morreau A (2003) Catchment characteristics and source water quality. In assessing microbial safety of drinking water. Improving approaches and method, WHO and OECD, IWA Publishing: London, UK, pp: 111-158.

7. Seas C, Alarcon M, Aragon JC, Beneit S, Quinonez M, et al. (2000) Surveillance of bacterial pathogens associated with acute diarrhea in Lima, Peru. Dis Int J Infect Dis 4: 96-99.

8. Fawole MO, Oso BA (1988) Laboratory manual of microbiology [1st edn], Spectrum Book Ltd, Ibadan. pp: 15-21.

9. Jay JM, Martin JL, David AG (2005) Modern food microbiology. $7^{\text {th }}$ New York.

10. Smith J, Edwards J, Hilger H, Steck RTR (2008) Sediment can be a reservoir for coliform bacteria released into streams. J Gen Appl Microbiol 54: 173-179.

11. Bailey SE, Olin TJ, Bricka RM, Adrian DD (1999) A review of potentially low-cost sorbent for heavy metals. Wter Research 33: 2469-2479.

12. Buttiaux R, Mossel DAA (1961) The significance of various organisms of faecal origin in food and drinking water. J. Appl. Microbiol 24: 353-364. 